\title{
POSITIVE IMPACT OF THE SNOEZELEN CONCEPT ON CHILDREN AND PUPILS WITH HEALTH DISABILITIES
}

\author{
Jarmila Pipeková \\ Jan Viktorin
}

\begin{abstract}
The literature review analyses 17 diploma theses which focus on the educational possibilities of using the Snoezelen concept in children and pupils with moderate, severe, and profound intellectual disabilities, multiple disabilities, autism spectrum disorder, and pupils with hearing impairment. Snoezelen is the name given to approaches, strategies, and special pedagogical support, implemented through various methods, techniques, and means to activate development, stimulate interest, motivate cognition, and mediate personal experience in people of different ages, but especially in children and pupils with multiple disabilities of different aetiology or causality. The results of the literature review clearly demonstrate the sustainability and high level of use of the Snoezelen concept in the education of pupils with severe disabilities in special schools, under the guidance of fully competent special educators during the period of compulsory education.
\end{abstract}

\section{Keywords}

literature review, Snoezelen, pupil with intellectual disability, pupil with autism spectrum disorder, pupil with multiple disabilities, special primary school

\section{Introduction}

Snoezelen is applicable to all target groups, whether in terms of age or ability. Since it does not require intellectual or other abilities, it is also suitable for children with severe disabilities. Snoezelen was primarily intended for these individuals. At present, it can benefit individuals with various types of disabilities, behavioural disorders, psychiatric diagnoses, dementia, traumatic brain injuries, chronic pain, individuals in palliative care, and able-bodied populations. Snoezelen can be defined as the induction of well-being and feelings of satisfaction through multisensory stimulation. The word Snoezelen is a portmanteau of two Dutch words: "snuffelen" (sniff) and "doezelen" 
(nap). The combination of these words completely and accurately captures the essence of the concept, which, on the one hand, helps subjects to relax and unwind thanks to the pleasant and calm atmosphere of its environment, and, on the other hand, supports activity and exploration, thanks to a stimulating and motivating environment. Snoezelen is a dynamic set of mental characteristics, based on a persistent sensitive relationship between the participant, a qualified guide, and a controlled environment, in which many possibilities for sensory stimulation are provided (Janků, 2018; Mertens, 2003; Orieščiková \& Hrčová, 2010).

A multisensory room should be a place where the individual has enough time and space to explore and interact with objects. If at all possible, they should have choice. Space, time, and the right to choose are related to the basic principle of Snoezelen: "nothing is necessary, everything is allowed". Mediation of mainly positive experiences and positive feedback is important. In a multisensory room, everything is set up so that it is possible to regulate the number and intensity of stimuli, and to adapt the environment according to the ability of an individual with a severe disability to process sensory stimuli. Individual stimuli can be intense enough for an individual with a severe disability to register and pay attention to, or alternatively, only gentle stimulation may be provided so that the individual's sensory tolerance is not exceeded should he or she respond hypersensitively to stimuli. It is advisable to choose a smaller number of stimuli (perhaps only one or two), with respect to the specifics of sensory perception of individuals with severe disabilities; while there may not be many sensory experiences, they may be more intense (Filatova, 2014; Švarcová, 2011; Verheul, 2008).

Individuals receive feedback on their competence to manipulate objects actively and independently in the room (in the form of sound or light), and are thus able to control and monitor their environment, which contributes to their development. Snoezelen is not just a means of relaxation and gaining new experiences. In multisensory rooms, it is possible to target the development of individual skills and abilities: perceptual, motor, cognitive, communication, and social. In addition, it also serves to eliminate inappropriate behaviour, and build a relationship with the person supervising Snoezelen. However, the highest and most important goal of Snoezelen is to create a feeling of wellbeing and security for users. When applying Snoezelen, one of four approaches can be selected. Snoezelen can be used as a leisure activity in which no specific goals are pursued and the Snoezelen session has a free flow. Currently, Snoezelen is more often used as a therapeutically-oriented approach with a certain goal, and, in the environment of Czech special schools, as a targeted pedagogical activity with a given educational goal. In these cases, the units should be thought out in advance, they should pursue a definite goal (in connection with the support of overall development), and the person working in the room should know the efficacy of individual aids and components, and should select and use them purposefully (Hulsegge \& Verheul, 1997; Janků, 2010; Mertens, 2005).

The multisensory environment/room can be equipped with a wide range of objects that are commonly used, or are intended primarily, for Snoezelen. It can be focused on stimulating one or two senses, or it can be equipped to stimulate all the senses. There are different variations of multisensory rooms or environments. The most universal 
and most used is the white room; however, other types of environment can be chosen, depending on the target group, their needs, and goals that we want to meet. In the Czech context, four types of environment are most often used: white, dark, and soft-play rooms, complemented by the so-called 'dream' or thematic room - an interesting element of support for individuals with severe disabilities and multiple disabilities (Orieščiková, 2015). Pagliano (2001) describes 12 embodiments of a multisensory environment. In addition to those already mentioned, these include a grey room, and other types of environments and zones, e.g., sound spaces, interactive zones, water zones, inclusive zones, virtual environments, social spaces, and pluralistic environments. He also refers to a portable environment that can be disassembled and packed up. This environment can, to some extent, be compared to mobile Snoezelen. In his more recent work, Pagliano (2012) adds other environments, such as olfactory, taste, and interoceptive spaces (an environment focused on the stimulation of interceptors, i.e., the vestibular apparatus and proprioception). The sound space is divided into two types, according to the intensity of the sounds (sharper sounds vs. more muted sounds).

The vestibular and proprioceptive system can be stimulated by a waterbed (it is still the basic element of many rooms), positioning bags, swings, or a pool filled with balls (it can also be backlit, which enhances the overall stimulation). These components are a source of stimuli to the body and are indispensable for individuals with severe and multiple disabilities. They allow us to gain experience of our own body, help us to understand it, and build a body scheme. In addition, the waterbed helps to relax muscles and encourages some degree of activity, as even the slightest movement on the bed will cause a movement effect. Different toys or objects of different structure, texture, shape, size, or weight can be used to stimulate touch. Another option is to install a tactile wall or panel, or a handling panel. Various odours are used to stimulate the sense of smell, which are used in a targeted way to achieve a certain state (relaxation, activation, support of attention, breathing, etc.) or to complete the overall atmosphere of the room. Sounds and music are indispensable. Music as a supporting or finishing element should meet certain criteria. Individuals in the room not only perceive the sounds (through music, toys, or simple instruments), but should also be guided to produce their own sounds. It is advisable to combine sounds with light or vibration. Visual stimuli are provided by the lighting of the room itself, which can be chosen in a targeted manner. Components may include bubble cylinders, optical fibres, projectors with rotating thematic patterns or projection of liquid oil paints, a mirror ball with a coloured reflector, etc. A very intense stimulus is mediated by UV light and UV reactive (phosphorescent) objects, which create a strong contrast to the rest of the environment, and stimulate individuals to activity, helping them utilize their residual visual abilities and supporting elementary visual abilities, such as localization, fixation, or tracking (Filatova \& Janků, 2011; Schwanecke, 2004; Vančová, 2010).

The rooms are (and should be) interactive in both social and technical senses; individuals with a severe disability are not limited to merely passively monitoring and receiving various stimuli but can evoke them themselves and get feedback on their own activity. Classic components, such as bubble cylinders or optical fibres, can be connected 
by special controllers with large buttons. With them, individuals can change the colour of fibres or cylinders. The control is simple and does not require much effort on the part of the individual. Thanks to these controls, it is possible for individuals with severe disabilities to be able to intervene in the arrangement of the environment actively and independently and evoke popular or preferred stimuli. In addition, interactive aids and interactive panels can be installed in the room, which respond to touch (for example, the pressing of a button) by turning on a light or changing colour, or by changing the light pattern. Verbal communication, or vocalization, can be supported by installation of components that respond to sound, e.g., by changing colour. Aids that respond to slight movement are also in place. In addition to visual feedback, the individual's activity can also prompt various sounds, music, smells, and vibrations, or activate a fan to allow the air flow to act on them. It is important that the room is safe with respect to movement and handling of objects, and that there is enough space in it to sit or lie down. It should be pleasant and, at the same time, motivate individuals to activity and cognition (Davies, 2012; Fowler, 2008; Opatřilová, 2013).

\section{Methodology}

The literature review has become the cornerstone of any relevant research in the field of special education. It is a method that is essential for the development of science in inclusive and special education. The importance of the literature review is given by the fact that no current research at any level can be undertaken without a thorough analysis and mapping of what has already been discovered in the research area, and how previous researchers have worked. Through a literature review, we can orient ourselves in the research area that we want to build on in our work (Bearman, Smith, Carbone, Slade, Baik, Hughes-Warrington, \& Neumann, 2012). A form of traditional (narrative) review was chosen for this literature review, which summarizes a larger set of studies on a given topic over a period. The study is based on carefully defined perspectives or selected research questions. It describes the findings from previous research, summarizes them, and identifies inconsistencies in the views of the authors and in the presented results of the authors. Thus, the review may contain more general recommendations and conclusions (Grant \& Booth, 2009).

The presented literature review reflects the question of the positive impact of the Snoezelen concept on children and pupils with health disabilities. To select studies suitable for analysis, we set two basic thematic criteria: individuals with disabilities, and the Snoezelen concept. We tried to grasp the chosen topic for the overview study comprehensively. By analysing and then synthesizing the knowledge, we decided to focus on the possibilities of educational use of the Snoezelen concept in children and pupils with moderate, severe, and profound intellectual disabilities, children and pupils with multiple disabilities, autism spectrum disorders, and hearing impairment.

For this purpose, according to the selected parameters, we performed a selection and subsequent analysis of 17 diploma theses of Masaryk University graduates which deal with our chosen topic. The collection and study of diploma theses was carried 
out at the beginning of 2021. We searched for diploma theses for the literature review in the archive of final theses on the university's web portal. We concentrated on thematically focused diploma theses in the period defined by the years 20062021. Based on the established criteria for the selection of suitable diploma theses, and according to the performed analysis, we synthesized the findings from relevant diploma theses into a literature review. We aimed to analyse individual selected diploma theses in a systematic review, then to give their brief characteristics, their contribution to theory and practice and, in general, to integrate knowledge on the topic of the positive impact of the Snoezelen concept on children and pupils with disabilities. Table 1 provides a general overview of the studies selected for this review.

Table 1 Overview of the analysed studies

\begin{tabular}{|c|c|c|c|c|}
\hline Author, year & Title & $\begin{array}{l}\text { Research } \\
\text { methods }\end{array}$ & $\begin{array}{c}\text { Research } \\
\text { sample }\end{array}$ & Research goal \\
\hline $\begin{array}{c}\text { Pešatová, M., } \\
2021\end{array}$ & $\begin{array}{c}\text { Development } \\
\text { of Sensory } \\
\text { Perception in } \\
\text { the Snoezelen } \\
\text { Room at a } \\
\text { Special Primary } \\
\text { School }\end{array}$ & $\begin{array}{l}\text { Qualitative } \\
\text { research using } \\
\text { techniques: } \\
\text { participatory } \\
\text { observation } \\
\text { (records on the } \\
\text { assessment } \\
\text { scale), analysis } \\
\text { of available } \\
\text { documents, } \\
\text { case studies }\end{array}$ & $\begin{array}{c}\text { Four pupils } \\
\text { of a special } \\
\text { primary school } \\
\text { (two girls and } \\
\text { two boys), } \\
\text { aged 8-14 } \\
\text { years }\end{array}$ & $\begin{array}{l}\text { To find out } \\
\text { whether } \\
\text { sensory } \\
\text { perception of } \\
\text { selected pupils } \\
\text { develops } \\
\text { during regular } \\
\text { stays in the } \\
\text { Snoezelen } \\
\text { multisensory } \\
\text { room }\end{array}$ \\
\hline $\begin{array}{c}\text { Piknerová, T., } \\
2020\end{array}$ & $\begin{array}{l}\text { The Influence } \\
\text { of the } \\
\text { Snoezelen } \\
\text { Concept on } \\
\text { the Social } \\
\text { Interaction } \\
\text { of Pupils } \\
\text { with Multiple } \\
\text { Disabilities }\end{array}$ & \begin{tabular}{|} 
Qualitative \\
research using \\
techniques: \\
direct \\
participatory \\
observation \\
(notes from \\
individual \\
lessons in \\
Snoezelen), \\
semi-structured \\
interviews \\
with pupils' \\
parents and \\
teachers, study \\
of documents, \\
case studies
\end{tabular} & $\begin{array}{c}\text { Five pupils } \\
\text { of a special } \\
\text { primary school } \\
\text { with multiple } \\
\text { disabilities } \\
\text { (four boys and } \\
\text { one girl), aged } \\
\text { 8-16 years }\end{array}$ & $\begin{array}{l}\text { To find out } \\
\text { what the } \\
\text { Snoezelen } \\
\text { concept } \\
\text { contributes } \\
\text { to the social } \\
\text { interaction } \\
\text { between a } \\
\text { pupil with } \\
\text { multiple } \\
\text { disabilities } \\
\text { and his/her } \\
\text { surroundings } \\
\text { (carer, family, } \\
\text { teachers, } \\
\text { peers) }\end{array}$ \\
\hline
\end{tabular}




\begin{tabular}{|c|c|c|c|c|}
\hline $\begin{array}{c}\text { Cmajdálková, D., } \\
2019\end{array}$ & $\begin{array}{l}\text { Structured } \\
\text { Teaching in } \\
\text { a Snoezelen } \\
\text { Environment } \\
\text { at a Special } \\
\text { Primary School }\end{array}$ & $\begin{array}{c}\text { Qualitative } \\
\text { research using } \\
\text { techniques: } \\
\text { case studies, } \\
\text { analysis of } \\
\text { documentation } \\
\text { (written notes, } \\
\text { photographs, } \\
\text { video } \\
\text { recordings), } \\
\text { observation, } \\
\text { interviews } \\
\end{array}$ & $\begin{array}{l}\text { Seven pupils } \\
\text { of a special } \\
\text { primary school } \\
\text { (three girls and } \\
\text { four boys), } \\
\text { aged 9-15 } \\
\text { years }\end{array}$ & $\begin{array}{l}\text { To find out } \\
\text { how structured } \\
\text { teaching in } \\
\text { the Snoezelen } \\
\text { environment } \\
\text { affects pupils } \\
\text { with different } \\
\text { types of } \\
\text { disabilities in a } \\
\text { special primary } \\
\text { school }\end{array}$ \\
\hline Krchová, D., 2019 & $\begin{array}{l}\text { Snoezelen as } \\
\text { a Means of } \\
\text { Developing } \\
\text { Sensory } \\
\text { Perception } \\
\text { in Pupils with } \\
\text { Moderate } \\
\text { and Severe } \\
\text { Intellectual } \\
\text { Disabilities }\end{array}$ & $\begin{array}{c}\text { Qualitative } \\
\text { research using } \\
\text { techniques: } \\
\text { analysis of } \\
\text { documentation, } \\
\text { case studies, } \\
\text { participatory } \\
\text { observation }\end{array}$ & $\begin{array}{l}\text { Seven pupils } \\
\text { with moderate } \\
\text { and severe } \\
\text { intellectual } \\
\text { disabilities } \\
\text { (four boys and } \\
\text { three girls), } \\
\text { aged 9-18 } \\
\text { years }\end{array}$ & $\begin{array}{l}\text { To find out } \\
\text { how the } \\
\text { Snoezelen } \\
\text { concept } \\
\text { develops } \\
\text { sensory } \\
\text { perception } \\
\text { in pupils with } \\
\text { moderate } \\
\text { and severe } \\
\text { intellectual } \\
\text { disabilities at } \\
\text { two special } \\
\text { primary } \\
\text { schools }\end{array}$ \\
\hline $\begin{array}{c}\text { Matějičcková, S., } \\
2019\end{array}$ & $\begin{array}{l}\text { Use of } \\
\text { Snoezelen } \\
\text { for Pupils } \\
\text { with Autism } \\
\text { Spectrum } \\
\text { Disorder }\end{array}$ & $\begin{array}{c}\text { Qualitative } \\
\text { research using } \\
\text { techniques: } \\
\text { case studies, } \\
\text { participatory } \\
\text { observation } \\
\text { (use of field } \\
\text { notes), } \\
\text { evaluation of } \\
\text { results based } \\
\text { on a specially } \\
\text { designed scale } \\
\text { (assessment } \\
\text { scale) }\end{array}$ & $\begin{array}{l}\text { Two pupils } \\
\text { (boys) of a } \\
\text { special primary } \\
\text { school, aged } \\
\text { 8-9 years }\end{array}$ & $\begin{array}{l}\text { To verify whether } \\
\text { Snoezelen has } \\
\text { a positive effect } \\
\text { on pupils with } \\
\text { autism spectrum } \\
\text { disorders in } \\
\text { the various } \\
\text { components } \\
\text { of the autism } \\
\text { spectrum } \\
\text { disorder triad: } \\
\text { communication, } \\
\text { socialization, and } \\
\text { imagination }\end{array}$ \\
\hline
\end{tabular}




\begin{tabular}{|c|c|c|c|c|}
\hline $\begin{array}{c}\text { Matějková, L., } \\
2018\end{array}$ & $\begin{array}{l}\text { The Use of } \\
\text { the Snoezelen } \\
\text { Concept in } \\
\text { the Education } \\
\text { of Pupils } \\
\text { with Severe } \\
\text { Intellectual } \\
\text { Disabilities }\end{array}$ & $\begin{array}{c}\text { Qualitative } \\
\text { research using } \\
\text { techniques: } \\
\text { analysis } \\
\text { of pupils' } \\
\text { documentation } \\
\text { (including } \\
\text { medical } \\
\text { reports and } \\
\text { reports } \\
\text { from special } \\
\text { education } \\
\text { centres), } \\
\text { participatory } \\
\text { observation } \\
\text { of pupils with } \\
\text { an evaluation } \\
\text { scale, } \\
\text { interviews with } \\
\text { parents, case } \\
\text { studies }\end{array}$ & $\begin{array}{c}\text { Five pupils } \\
\text { of a special } \\
\text { primary school } \\
\text { with severe } \\
\text { intellectual } \\
\text { disabilities } \\
\text { and multiple } \\
\text { disabilities (two } \\
\text { boys and three } \\
\text { girls), aged 15- } \\
19 \text { years }\end{array}$ & $\begin{array}{l}\text { To verify the } \\
\text { specifics of } \\
\text { the use of the } \\
\text { Snoezelen } \\
\text { concept in } \\
\text { the education } \\
\text { of pupils } \\
\text { with severe } \\
\text { intellectual } \\
\text { disabilities at a } \\
\text { special primary } \\
\text { school }\end{array}$ \\
\hline $\begin{array}{c}\text { Saňáková, J., } \\
2018\end{array}$ & $\begin{array}{l}\text { Use of the } \\
\text { Concept } \\
\text { of Basal } \\
\text { Stimulation } \\
\text { and the } \\
\text { Method of } \\
\text { Snoezelen at a } \\
\text { Special Primary } \\
\text { School }\end{array}$ & $\begin{array}{c}\text { Qualitative } \\
\text { research using } \\
\text { techniques: } \\
\text { case studies, } \\
\text { analysis of } \\
\text { documentation, } \\
\text { active } \\
\text { observation, } \\
\text { semi-structured } \\
\text { interviews with } \\
\text { a class teacher, } \\
\text { teaching } \\
\text { assistants, and } \\
\text { parents }\end{array}$ & $\begin{array}{l}\text { Six pupils of a } \\
\text { special primary } \\
\text { school with } \\
\text { moderate, } \\
\text { severe, } \\
\text { profound } \\
\text { intellectual } \\
\text { disabilities, } \\
\text { multiple } \\
\text { disabilities, } \\
\text { and autism } \\
\text { spectrum } \\
\text { disorder (three } \\
\text { girls and three } \\
\text { boys), aged } \\
\text { 9-14 years }\end{array}$ & $\begin{array}{l}\text { To analyse } \\
\text { the influence } \\
\text { of basal } \\
\text { stimulation and } \\
\text { the Snoezelen } \\
\text { method on } \\
\text { pupils at a } \\
\text { special primary } \\
\text { school }\end{array}$ \\
\hline
\end{tabular}




\begin{tabular}{|c|c|c|c|c|}
\hline Dítětová, J., 2016 & $\begin{array}{c}\text { The Use of } \\
\text { the Snoezelen } \\
\text { Concept } \\
\text { to Support } \\
\text { Education at a } \\
\text { Special Primary } \\
\text { School }\end{array}$ & $\begin{array}{l}\text { Qualitative } \\
\text { research using } \\
\text { techniques: } \\
\text { analysis of } \\
\text { pedagogical } \\
\text { documentation, } \\
\text { direct } \\
\text { observation } \\
\text { of pupils, } \\
\text { special work } \\
\text { with pupils, } \\
\text { interview with } \\
\text { teachers and } \\
\text { parents }\end{array}$ & $\begin{array}{c}\text { Five pupils } \\
\text { of a special } \\
\text { primary school } \\
\text { with moderate, } \\
\text { severe } \\
\text { intellectual } \\
\text { disabilities } \\
\text { and multiple } \\
\text { disabilities } \\
\text { (three girls } \\
\text { and two boys), } \\
\text { aged } 10-13 \\
\text { years }\end{array}$ & $\begin{array}{l}\text { To verify the } \\
\text { use of the } \\
\text { Snoezelen } \\
\text { concept in } \\
\text { the education } \\
\text { of pupils at a } \\
\text { special primary } \\
\text { school }\end{array}$ \\
\hline Macků, K., 2016 & $\begin{array}{l}\text { Efficacy of } \\
\text { Aids used in } \\
\text { Snoezelen } \\
\text { in Children } \\
\text { with Autism } \\
\text { Spectrum } \\
\text { Disorder of } \\
\text { Preschool Age }\end{array}$ & $\begin{array}{l}\text { Qualitative } \\
\text { research using } \\
\text { techniques: } \\
\text { case studies, } \\
\text { observation, } \\
\text { interviews, } \\
\text { analysis of } \\
\text { professional } \\
\text { medical, } \\
\text { pedagogical, } \\
\text { and } \\
\text { psychological } \\
\text { documents, } \\
\text { results } \\
\text { recorded in } \\
\text { record sheets } \\
\text { and evaluated } \\
\text { based on } \\
\text { scaling using } \\
\text { purposely } \\
\text { designed scale }\end{array}$ & $\begin{array}{l}\text { Four children } \\
\text { (boys) with } \\
\text { autism } \\
\text { spectrum } \\
\text { disorder, aged } \\
\text { 4-6 years }\end{array}$ & $\begin{array}{l}\text { To verify the } \\
\text { effectiveness of } \\
\text { the aids used } \\
\text { in Snoezelen } \\
\text { in children } \\
\text { with autism } \\
\text { spectrum } \\
\text { disorder }\end{array}$ \\
\hline
\end{tabular}




\begin{tabular}{|c|c|c|c|c|}
\hline $\begin{array}{l}\text { Nečasová, L., } \\
2015\end{array}$ & $\begin{array}{c}\text { Development } \\
\text { of Sensory } \\
\text { Perception in } \\
\text { the Snoezelen } \\
\text { Room at the } \\
\text { Special Primary } \\
\text { School for } \\
\text { Pupils with } \\
\text { Moderate } \\
\text { and Severe } \\
\text { Intellectual } \\
\text { Disabilities }\end{array}$ & $\begin{array}{c}\text { Qualitative } \\
\text { research using } \\
\text { techniques: } \\
\text { case studies, } \\
\text { analysis } \\
\text { of pupils' } \\
\text { personal file } \\
\text { documentation, } \\
\text { record } \\
\text { sheets, non- } \\
\text { participatory } \\
\text { observation, } \\
\text { records with } \\
\text { inventories } \\
\end{array}$ & $\begin{array}{c}\text { Seven pupils } \\
\text { of a special } \\
\text { primary school } \\
\text { (five boys and } \\
\text { two girls), aged } \\
\text { 8-13 years }\end{array}$ & $\begin{array}{l}\text { To find out } \\
\text { how senses } \\
\text { develop in } \\
\text { pupils with } \\
\text { moderate } \\
\text { and severe } \\
\text { intellectual } \\
\text { disabilities in } \\
\text { the Snoezelen } \\
\text { room at two } \\
\text { special primary } \\
\text { schools }\end{array}$ \\
\hline Zedková, B., 2014 & $\begin{array}{l}\text { Possibilities } \\
\text { of Using the } \\
\text { Snoezelen } \\
\text { Method in } \\
\text { the Education } \\
\text { of Pupils } \\
\text { with Severe } \\
\text { Disabilities } \\
\text { and Multiple } \\
\text { Disabilities }\end{array}$ & \begin{tabular}{|} 
Qualitative \\
research using \\
techniques: \\
analysis of \\
pedagogical \\
documents \\
(pupil \\
documentation), \\
participatory \\
observation \\
(notes, \\
observation \\
records), \\
interviews with \\
teachers, case \\
studies \\
\end{tabular} & $\begin{array}{c}\text { Two pupils } \\
\text { (boys) of } \\
\text { a special } \\
\text { primary school } \\
\text { with severe } \\
\text { disabilities } \\
\text { and multiple } \\
\text { disabilities, } \\
\text { aged } 11-17 \\
\text { years }\end{array}$ & $\begin{array}{l}\text { To determine } \\
\text { the influence } \\
\text { of Snoezelen } \\
\text { on selected } \\
\text { personality } \\
\text { components } \\
\text { of pupils } \\
\text { with severe } \\
\text { disabilities } \\
\text { and multiple } \\
\text { disabilities }\end{array}$ \\
\hline $\begin{array}{c}\text { Krausová, V., } \\
2013\end{array}$ & $\begin{array}{c}\text { Use of } \\
\text { Multisensory } \\
\text { Room } \\
\text { Snoezelen } \\
\text { and Elements } \\
\text { of Basal } \\
\text { Stimulation } \\
\text { in Children } \\
\text { with Severe } \\
\text { Disabilities }\end{array}$ & $\begin{array}{c}\text { Qualitative } \\
\text { research using } \\
\text { techniques: } \\
\text { participatory } \\
\text { observation, } \\
\text { analysis } \\
\text { of pupils' } \\
\text { personal } \\
\text { and school } \\
\text { documentation, } \\
\text { unstructured } \\
\text { interviews with } \\
\text { pupils' parents } \\
\text { and teachers, } \\
\text { case studies } \\
\end{array}$ & $\begin{array}{l}\text { Three pupils } \\
\text { of a special } \\
\text { primary school } \\
\text { (one boy and } \\
\text { two girls), aged } \\
7-13 \text { years }\end{array}$ & $\begin{array}{l}\text { To analyse } \\
\text { and evaluate } \\
\text { the use of the } \\
\text { Snoezelen } \\
\text { multisensory } \\
\text { room in the } \\
\text { intellectual } \\
\text { (attention, } \\
\text { concentration) } \\
\text { and social } \\
\text { (interaction } \\
\text { with others) } \\
\text { area, for pupils } \\
\text { with severe } \\
\text { disabilities }\end{array}$ \\
\hline
\end{tabular}




\begin{tabular}{|c|c|c|c|c|}
\hline Cacková, A., 2009 & $\begin{array}{l}\text { Use of } \\
\text { Snoezelen as } \\
\text { a Prevention } \\
\text { of Self-harm } \\
\text { in Individuals } \\
\text { with Multiple } \\
\text { Disabilities }\end{array}$ & $\begin{array}{l}\text { Qualitative } \\
\text { research using } \\
\text { techniques: } \\
\text { analysis of } \\
\text { documents } \\
\text { (medical, } \\
\text { pedagogical, } \\
\text { psychological, } \\
\text { etc.), } \\
\text { observation, } \\
\text { interviews } \\
\text { with teachers, } \\
\text { analysis of } \\
\text { activity results, } \\
\text { case studies }\end{array}$ & $\begin{array}{c}\text { Four pupils } \\
\text { of a special } \\
\text { primary } \\
\text { school with } \\
\text { manifestations } \\
\text { of self-harm, } \\
\text { aged 6-19 } \\
\text { years }\end{array}$ & $\begin{array}{l}\text { To verify the } \\
\text { importance } \\
\text { of using } \\
\text { Snoezelen as } \\
\text { a prevention } \\
\text { of self-harm } \\
\text { in individuals } \\
\text { with multiple } \\
\text { disabilities }\end{array}$ \\
\hline $\begin{array}{l}\text { Plecháčková, M., } \\
2009\end{array}$ & $\begin{array}{c}\text { Use of } \\
\text { Multisensory } \\
\text { Room } \\
\text { Snoezelen } \\
\text { for Children } \\
\text { with Hearing } \\
\text { Impairment }\end{array}$ & $\begin{array}{l}\text { Qualitative } \\
\text { research using } \\
\text { techniques: } \\
\text { document } \\
\text { analysis, semi- } \\
\text { standardized } \\
\text { interviews } \\
\text { with teachers } \\
\text { and pupils, } \\
\text { observation, } \\
\text { natural } \\
\text { experiments } \\
\text { with pupils, } \\
\text { case studies }\end{array}$ & $\begin{array}{c}\text { Four pupils } \\
\text { attending } \\
\text { primary school } \\
\text { for the hearing } \\
\text { impaired (three } \\
\text { boys and one } \\
\text { girl), aged } 11- \\
14 \text { years }\end{array}$ & $\begin{array}{l}\text { To describe } \\
\text { the Snoezelen } \\
\text { multisensory } \\
\text { room and the } \\
\text { possibilities of } \\
\text { its use in the } \\
\text { field of special } \\
\text { education }\end{array}$ \\
\hline
\end{tabular}




\begin{tabular}{|c|c|c|c|c|}
\hline $\begin{array}{c}\text { Šoupalová, J., } \\
2009\end{array}$ & $\begin{array}{l}\text { Aspects of } \\
\text { Using the } \\
\text { Snoezelen } \\
\text { Multisensory } \\
\text { Room }\end{array}$ & $\begin{array}{l}\text { Qualitative } \\
\text { research using } \\
\text { techniques: } \\
\text { qualitative } \\
\text { observation } \\
\text { (participial } \\
\text { observation), } \\
\text { qualitative } \\
\text { questioning } \\
\text { (standardized } \\
\text { interview } \\
\text { with closed } \\
\text { questions), } \\
\text { qualitative } \\
\text { methods of } \\
\text { data collection, } \\
\text { field notes }\end{array}$ & $\begin{array}{c}\text { Four special } \\
\text { educators } \\
\text { from three } \\
\text { facilities (home } \\
\text { for people } \\
\text { with health } \\
\text { disabilities, } \\
\text { primary school } \\
\text { and practical } \\
\text { school, special } \\
\text { school) }\end{array}$ & $\begin{array}{c}\text { To provide } \\
\text { the widest } \\
\text { possible range } \\
\text { of information } \\
\text { regarding the } \\
\text { effective use of } \\
\text { the Snoezelen } \\
\text { multisensory } \\
\text { room and the } \\
\text { possibility of } \\
\text { increasing the } \\
\text { quality of life } \\
\text { and personality } \\
\text { development } \\
\text { of pupils } \\
\text { with severe } \\
\text { intellectual } \\
\text { disabilities } \\
\text { and multiple } \\
\text { disabilities } \\
\text { through a } \\
\text { consciously } \\
\text { selected and } \\
\text { manageable } \\
\text { offer of primary } \\
\text { stimuli in a } \\
\text { pleasant and } \\
\text { safe Snoezelen } \\
\text { atmosphere }\end{array}$ \\
\hline
\end{tabular}




\begin{tabular}{|c|c|c|c|c|}
\hline $\begin{array}{c}\text { Vostrejšová, D., } \\
2009\end{array}$ & $\begin{array}{l}\text { The Effect of } \\
\text { Snoezelen in } \\
\text { the Stimulation } \\
\text { of Individuals } \\
\text { with Severe } \\
\text { and Multiple } \\
\text { Disabilities }\end{array}$ & $\begin{array}{c}\text { Qualitative } \\
\text { research using } \\
\text { techniques: } \\
\text { analysis of } \\
\text { professional } \\
\text { texts and } \\
\text { documents, } \\
\text { long-term } \\
\text { observation, } \\
\text { active work } \\
\text { with the } \\
\text { monitored } \\
\text { pupils, } \\
\text { interviews with } \\
\text { therapists and } \\
\text { pedagogical } \\
\text { staff, case } \\
\text { studies } \\
\end{array}$ & $\begin{array}{c}\text { Four pupils } \\
\text { of a special } \\
\text { primary school } \\
\text { (two boys and } \\
\text { two girls), aged } \\
11-16 \text { years }\end{array}$ & $\begin{array}{l}\text { To verify the } \\
\text { positive effect } \\
\text { of perception } \\
\text { of basic } \\
\text { sensory stimuli } \\
\text { (auditory, } \\
\text { visual, } \\
\text { olfactory, } \\
\text { tactile, and } \\
\text { taste) in the } \\
\text { environment } \\
\text { of Snoezelen } \\
\text { on individuals } \\
\text { with severe } \\
\text { disabilities } \\
\text { and multiple } \\
\text { disabilities }\end{array}$ \\
\hline $\begin{array}{l}\text { Krzyžanková, L., } \\
2006\end{array}$ & $\begin{array}{c}\text { Snoezelen as } \\
\text { a Method of } \\
\text { Positive Basal } \\
\text { Stimulation }\end{array}$ & $\begin{array}{c}\text { Qualitative } \\
\text { research using } \\
\text { techniques: } \\
\text { analysis of } \\
\text { records about } \\
\text { pupils in the } \\
\text { monitored } \\
\text { class, free } \\
\text { observation } \\
\text { of situations, } \\
\text { structured } \\
\text { observation } \\
\text { according } \\
\text { to selected } \\
\text { categories, } \\
\text { natural } \\
\text { experiments } \\
\text { with pupils, } \\
\text { non- } \\
\text { standardized } \\
\text { interviews with } \\
\text { pupils' parents, } \\
\text { analysis of } \\
\text { results of } \\
\text { selected } \\
\text { pupils' } \\
\text { activities }\end{array}$ & $\begin{array}{l}\text { Six pupils of a } \\
\text { special primary } \\
\text { school (two } \\
\text { boys and four } \\
\text { girls), aged } \\
\text { 9-17 years }\end{array}$ & $\begin{array}{l}\text { To verify the } \\
\text { positive impact } \\
\text { and effect of } \\
\text { perception of } \\
\text { basal sensory } \\
\text { stimuli in } \\
\text { pupils at a } \\
\text { special primary } \\
\text { school }\end{array}$ \\
\hline
\end{tabular}




\section{Results of the Review}

In a study, Pešatová (2021) investigated whether sensory perception develops in a multisensory room during regular targeted educational activities of selected pupils with severe intellectual disabilities. The research involved four pupils attending the same class (two girls and two boys aged 8-14) who visited the Snoezelen room once a week for the duration of the study. The study was carried out in the form of a long-term direct observation for six months, during which time data were collected to compare pupils' progress in sensory perception, their mental well-being, and whether their Snoezelen experiences were transferred to the classroom. After the end of the research, it was confirmed that Snoezelen had had a significant influence on the development of sensory perception in pupils with severe intellectual disabilities, since in each of them there had been some improvement in sensory perception. Research has shown that the more often individual senses are stimulated, the more often pupils use them to explore the immediate area outside the Snoezelen room. During the research period, it was also found that the observed pupils experienced an increase in their sense of security and general relaxation during their stay in Snoezelen. Targeted activities affected the mood and mental state of the pupils. There were no negative reactions during Snoezelen activities; on the contrary, expressions of pleasure, e.g., smiles and even audible laughter, were observed in the pupils. The study indicated that being in the Snoezelen room helped to improve the mental well-being of pupils.

The goal of Piknerová's research (2020) was to analyse the ability of pupils with multiple disabilities to interact socially after regular targeted educational activities in the Snoezelen room. The study focused mainly on the development of relationships and ties with family members, teachers, and peers, and examined the effects of the concept on the educational process, the development of sensory perception, communication, and emotionality of pupils. The research consisted of processing five case studies of pupils with multiple disabilities, mapping family relationships, health status, and social, personal, and school history. By directly observing the educational activities in the regular classroom and in the Snoezelen room during one school year, data were collected to compare the development of pupils in the monitored areas. The study found that there was no drastic progress in the monitored pupils in any of the defined categories. However, there were small changes in their ability to use visual perception (in the form of more frequent monitoring of classmates and activities in joint activities), more frequent reactions when addressed and given verbal instructions by the teacher, some use of hands for physical contact with other classmates, and slight progress in activating communication. It can therefore be assumed that the use of Snoezelen had an impact on the development of pupils' communication with their environment. Although the researcher found only minimal shifts in development in the monitored areas for participants, it can also be assumed that Snoezelen influenced the formation of social interaction in the monitored pupils with multiple disabilities. 
In another study, Cmajdálková (2019) investigated how structured teaching in the Snoezelen environment affected special school pupils with various types of disabilities (including severe intellectual disabilities, multiple disabilities, and autism spectrum disorders) in terms of cognitive functions (thinking, memory), behaviour, and communication; and also explored the specifics that should be considered in the teaching of pupils with different types of disability. The qualitative research used the case studies of seven pupils and included observation and interviews with teachers. Structured teaching in the Snoezelen environment positively influenced the cognitive functions and behaviour of pupils, especially pupils with moderate intellectual disabilities, but also pupils with severe and profound intellectual disabilities. Following consistent long-term enrolment, positive changes of a qualitative nature could be observed in the monitored areas. Education in the Snoezelen environment played an irreplaceable role in the development and education of these pupils.

The main goal of Krchová's study (2019) was to establish how sensory perception is developed in pupils in a special primary school with moderate and severe intellectual disabilities through the Snoezelen concept. The author adopted a qualitative research strategy, involving techniques of document analysis, case studies of pupils, and participatory observation. The study ran for two months, with the research sample consisting of seven pupils. The observed lessons in Snoezelen showed that the pupils' individual senses were not developed to the same extent, so it can be concluded that the degree of development of individual senses depends on the content of lessons (structured thematic lessons that seek to develop all the senses, taking into consideration the individual needs of the pupils), the pupils' diagnoses, and the approach, abilities, interest, and education of the teacher or therapist who leads the lesson. The research survey recommended focusing on the development of all senses, especially stimulation of the (very often neglected) sense of taste.

Matějičková (2019) carried out a study on the use of Snoezelen in pupils with autism spectrum disorder. The goal of the research was to verify whether Snoezelen had a positive effect on pupils with autism spectrum disorder in targeted development of communication, socialization, and imagination. The selected qualitative methodology of the study used the techniques of case studies, and participatory observation using evaluation with an assessment scale. The research sample consisted of two pupils aged eight and nine years diagnosed with autism spectrum disorder. The results of the study showed that Snoezelen was beneficial to the development of pupils with autism spectrum disorder in the triad of disabilities (communication, socialization, and imagination). The research indicated that Snoezelen did not develop every component of each pupil's triad of difficulties, but suggested that Snoezelen generally had a positive effect on pupils with autism spectrum disorders and could help them with deficits in communication, socialization, and imagination. In the field of communication, there were developments in vocabulary, and in understanding the meaning and significance of communication (in the sense of influencing reality). The development of socialization was a guided effort to reduce aggression, calm the individual, develop social relationships/teacher-child 
relationships, suppress unwanted behaviour, and improve mental well-being. In the field of imagination, a better transition between individual activities, and better acceptance of the offered stimuli were attempted.

The study by Matějková (2018) aimed to verify the specifics of using the Snoezelen concept in the education of pupils with severe intellectual disabilities to find out: how pupils respond to new stimuli in the Snoezelen environment, whether pupils with severe intellectual disabilities are calmed by this environment, and in which areas the Snoezelen concept can help pupils with severe intellectual disabilities to develop. The qualitative research applied the techniques of analysis of pupils' documentation, participatory observation of pupils, and interviews with parents. The information from the observation of participants was supplemented by an analysis of the available documentation: i.e., everything that was officially and unofficially recorded, including notes. As part of the study, five case studies (of two boys and three girls aged 15-19) were selected. The analysis of the outcomes of the activity took place in pre-prepared structured Snoezelen lessons, which the pupils attended during morning lessons two-three times a week. The study indicated that the Snoezelen concept is a very suitable means of supplementing pupils' education. The obtained results showed that repeated stays of these pupils had a positive effect on the development of their personality. It is important not to neglect any of the senses that can be stimulated in pupils in preparation for Snoezelen. All pupils responded positively to the stimuli offered in a multisensory environment, or new stimuli received after repeated visits to the Snoezelen room.

The main goal of a study by Saňáková (2018) was to analyse the impact of the Snoezelen concept on pupils with autism spectrum disorders, and on pupils with profound intellectual disabilities. The research aimed to analyse whether Snoezelen improved communication and calm behaviour in pupils with autism spectrum disorder. For pupils with profound intellectual disabilities, it focused on improving gross motor skills, self-perception, and pupils' response to bodily contact. The method of qualitative research was chosen for the study, using the techniques of processing case studies (supplemented with information from the pupils' parents), active observation, and semi-structured interviews with the class teacher and teaching assistants. The research took place over a period of 18 months and involved six pupils of a special primary school (with autism spectrum disorders, moderate, severe, and profound intellectual disabilities). As a result of the study it can be stated that the contribution of Snoezelen to the education of the selected sample of pupils was considerable, but it was not possible to compare the progress in the development of individual pupils due to differences in type of disability and age. The main goal of a study by Dítětová (2016) was to verify the use of Snoezelen in the education of pupils in a special primary school. The study used qualitative research methods, including analysis of pedagogical documentation, direct observation of pupils, special work with selected pupils, and interviews with teachers and parents. Five case studies of selected pupils aged 10-13 years were processed. The study found that Snoezelen offered a relatively large range of uses for working with pupils in a special primary school. It was possible to use it purposefully in the educational process 
as a change of environment that was interesting and attractive for pupils, and pupils were calmer and more focused in the Snoezelen environment. Another way of using Snoezelen is in combination with basal stimulation, which is important in helping pupils with severe disabilities to relax. The study indicated that Snoezelen was suitable for use in primary schools, especially for education, rehabilitation, and relaxation.

Macků (2016) aimed to verify the effectiveness of aids used in Snoezelen in children with autism spectrum disorder in preschool education. The study was carried out through qualitative research using case studies, which were processed by techniques of observation, interviews, and analysis of professional medical, pedagogical, and psychological documents. Subsequently, the results were recorded in record sheets, which were evaluated based on scaling. The research sample consisted of four preschool children with autism spectrum disorder. The research was carried out over six months, during which time Snoezelen was gradually included in teaching. The key to choosing aids is to meet conditions for the development of the senses: namely aids that stimulate sight, hearing, touch, and the vestibular apparatus. According to the results of the study, the use of the Snoezelen method had a very positive effect on the whole personality of children with autism spectrum disorder, with positive results reflected in both their education and everyday life.

The main goal of Nečasová's research (2015) was to determine how the senses developed in pupils with moderate and severe intellectual disabilities in the Snoezelen room, and whether all their senses developed equally. A qualitative strategy was chosen for the study. Short case studies of seven pupils aged 8-13 studying at a special primary school were included. Record sheets were used to record the events in Snoezelen, and the technique of non-participatory observation was used for data collection. The research indicated that ways of developing the senses were different, depending on many aspects: e.g., the teacher who led the lesson, the pupil, his/her type and degree of disability, his/her current mood, and the aids used in the lesson. The study concluded that the individual senses were not developed to an equal extent in the monitored group of pupils; visual and auditory stimuli were developed in each monitored lesson, olfactory stimuli were supported in the middle of the observed lessons, and olfactory stimuli were not included in the teaching at all. The author of the study recommended that teaching in Snoezelen be based on a holistic approach, with all senses developed with the same intensity.

The study by Zedková (2014) aimed to determine the influence of Snoezelen on selected components of personality (level of communication, ability to respond to the stimuli presented) and the influence of Snoezelen on the psychological well-being of the pupil. The author based the study on qualitative research methods, elaborating the case studies of two pupils with severe disabilities and multiple disabilities who purposefully participated in education in the Snoezelen room for almost one year. Stays in the room took place regularly once a week. The results of the research showed that the use of the Snoezelen method was beneficial for both pupils. Staying in a multisensory room provided them with a pleasant environment for relaxation, unwinding, the opportunity to get to know 
each other, better interaction with the environment, and further development of their abilities.

Krausová (2013) dealt with the issue of supporting pupils with severe disabilities through elements of basal stimulation, applied in the multisensory environment of Snoezelen. The goal of the research was to analyse the use of multisensory room Snoezelen. The researcher focused on: monitoring the reactions of a selected group of pupils (three pupils from different classes aged 7-13: one boy, two girls) to new stimuli; the pupils' reactions to teachers and classmates in the Snoezelen room; and analysis of the use of basal stimulation of pupils with regard to visual, auditory, and somatic stimuli. A qualitative research approach was chosen for the study, applying the technique of participatory observation, which was crucial to the implementation of this research. The study continued for one school year, twice a week for 45 minutes. All results obtained indicated that the repeated stay of pupils with severe disabilities in Snoezelen increased their attention and ability to concentrate. This subsequently manifested itself both in the activities in Snoezelen and in regular schooling. Cooperation with pupils improved overall. Pupils concentrated longer in lessons, and their acquisition of new skills was faster. The results of the study indicated a positive influence on the development of the interactions of the observed pupils with teachers and other classmates. The pupils began to accept contact more readily, and, at the same time, to initiate it more themselves. The greatest progress was made in the development of interactions that occurred through somatic stimulation. Based on the results of the research survey, it can be stated that it is appropriate for all pupils to use targeted activities in the Snoezelen environment for their development, which should be supplemented by basal stimulation. The goal of the study by Cacková (2009) was to verify the importance of using Snoezelen as a prevention against self-harm in pupils with multiple disabilities. A qualitative method was chosen for the research survey, involving observation techniques, interviews, document analysis, and analysis of activity results. For the research project, four special primary school pupils with multiple disabilities and diagnosed as self-harming, were selected. The research focused on whether the inclusion of basal stimulation and massage activities in Snoezelen allowed individuals to gain a positive experience through their body, and whether these activities contributed to an overall calming of the pupils. During the study, it was found that manifestations of self-harm were influenced by many factors, and therefore it could not be stated unequivocally that the inclusion of activities in Snoezelen alone reduced the manifestations and intensity of self-harm. However, the conclusions of the research confirmed that the use of basal stimulation, massage, and Snoezelen are of great importance to the development of pupils with multiple disabilities, providing them with positive experiences gained through their body after application of basal stimulation. However, in each activity, it is necessary to monitor pupils' reactions and include and develop those activities in which a positive response and self-assurance of the pupil is evident.

Plecháčková (2009) carried out a study dealing with the use of the Snoezelen multisensory room in pupils with hearing impairment. The goal was to describe the functioning 
of Snoezelen in a school for pupils with hearing impairment, to verify the benefits of the multisensory room when working with pupils with hearing impairment (to find out whether staying in a multisensory room and applying methods can be beneficial for such pupils), and to characterize the advantages and disadvantages of methods and procedures used for working in the Snoezelen multisensory room with pupils with hearing impairment. To meet the research goal, the author chose a qualitative strategy using research techniques of document analysis, interviews, observation, natural experiment, and case studies of four pupils aged 11-14 from a primary school for pupils with hearing impairment, for one school year. The results of the research showed that the use of Snoezelen in pupils with hearing impairment was appropriate. Activities carried out in this room corresponded to the specific needs of these pupils. Based on longterm observations, the advantages, and disadvantages of including these methods in the educational process at primary school for pupils with hearing impairment were specified. One advantage is the possibility of applying special pedagogical procedures with therapeutic elements; Snoezelen is suitable for all age groups of pupils, for school counselling centres, for school groups, and for pupils in their free time. Disadvantages are the higher financial costs of the establishment of Snoezelen at schools, the need for further education of teaching staff, and organizational issues around the inclusion of the use of Snoezelen in schools.

Šoupalová's research (2009) dealt with the issue of mediating the widest possible range of information regarding the effective use of the Snoezelen multisensory room, and the possibility of improving the quality of life of people with severe intellectual disabilities and multiple disabilities through a targeted offer of primary stimuli in a safe Snoezelen atmosphere. The study took place in three facilities in which the Snoezelen multisensory room was used for various selected activities: therapeutic activities, animal therapy (dog), music therapy, and targeted support of visual perception in the form of light effects. A qualitative research method was chosen for the study, using techniques of participatory observation, standardized interviews with closed questions, and data collection with field notes. The research sample consisted of four special educators who had long-term experience of working in Snoezelen. In monitored facilities, use of the Snoezelen multisensory room is an extremely beneficial approach, provided mainly to individuals with severe intellectual disabilities and concurrent multiple disabilities. It is difficult to approximate the way of experiencing reality, thinking, and perception of these individuals. One option is Snoezelen and the use of the multisensory room, which allows the arousal of individual sensations. The multisensory stimulation that takes place in Snoezelen is one of the most common and successful approaches, not only with regard to learning, but also to therapeutic procedures for people with severe disabilities. The study carried out by Vostrejšová (2009) aimed to verify the positive effect of basic sensory stimuli (auditory, visual, olfactory, tactile, and taste) in the environment of Snoezelen on individuals with severe disabilities and multiple disabilities. The study employed qualitative research techniques of analysis of pupil records, and elaboration of case studies of four selected pupils (pupils who were immobile, with multiple 
disabilities, or with severe to profound intellectual disabilities). One of the main methods used in the education of these pupils is multi-stimulation method Snoezelen. In an artificially created environment, pupils with severe disabilities have deep experiences that they would not have the chance to experience in everyday life. Snoezelen is one of the ways to offer a form of self-realization to pupils with severe disabilities and limited opportunities to perform activities by themselves, allowing them to enjoy success, joy, and other sensations that they would not otherwise experience. In all the monitored pupils, Snoezelen had a positive effect on the improvement of their quality of life; during the planned activities, the pupils were generally reassured and the connection with the teacher was strengthened.

The main goal of the study by Krzyžanková (2006) was to verify the expected positive impact and effect of perception of basal sensory stimuli in pupils with severe and profound disabilities and multiple disabilities educated at a special primary school. The chosen qualitative strategy of the study and the techniques applied (analysis of pupils' records, structured observation according to selected categories, natural experiments, interviews with pupils' parents, and analysis of results of pupils' activities) gave the researcher a deep insight into the education of pupils with multiple disabilities. Pupils with severe disabilities usually lack the stimuli for their development, and this can increase their disability. The Snoezelen concept is based on a holistic approach to individuals with severe disabilities, fulfilling their needs for acceptance, understanding, closeness and, if possible, sensory perception and experience. The more severe the degree of intellectual disability in pupils, the more appropriate sensory stimulation of pupils becomes for their development. The use of therapies in Snoezelen rooms is met with great enthusiasm by both pupils and special educators. Snoezelen is perceived as a place to meet, to strengthen mutual belonging, a place where they experience joy, where they feel 'good', and where it is possible to create a sense of security in pupils. The study indicated a positive impact of the use of Snoezelen in targeted educational activities of pupils with severe intellectual disabilities and multiple disabilities.

\section{Conclusion}

The studies that we have presented in the text are monothematic and focus on the use of the Snoezelen concept in the field of support and education of pupils with severe disabilities and multiple disabilities who are educated in special schools. In the analysed studies, the issue of supporting educational goals for these pupils prevails; in most research, the achievement of these educational goals involves Snoezelen in conjunction with another concept of support, i.e., basal stimulation. The analysis of studies confirmed the expected results of using Snoezelen in the environment of special schools to achieve educational goals set by special educators with high professional knowledge. In most research, we learn how well-equipped the Snoezelen rooms are in special schools, which predominate in providing this specific support to individuals with severe disabilities. 
Of the 17 selected studies, 14 dealt with the support of pupils with severe disabilities and multiple disabilities, two focused on the support of pupils with autism spectrum disorder, one on preschool children, and one on pupils with hearing impairment. Based on our analysis of the selected studies, it can be stated that Snoezelen is most often used in special schools that educate children and pupils with severe disabilities or multiple disabilities, and that special educators who work at these schools manage their pupils with Snoezelen and basal high-level stimulation. These concepts are currently the main educational methods in special schools for pupils with severe disabilities, complemented by other therapeutic and formative approaches. The results of the survey study, which focused on the use of the Snoezelen concept, clearly demonstrate the sustainability and high level of use of this concept in the education of pupils with severe disabilities during compulsory education in special schools and under the guidance of fully competent special educators.

\section{References}

Bearman, M. L., Smith, C., Carbone, A., Slade, S., Baik, C., Hughes-Warrington, M. T. E., \& Neumann, D. L. (2012). Systematic Review Methodology in Higher Education. Higher Education Research and Development, 31(5), 625-640.

Cacková, A. (2009). Využití Snoezelenu jako prevence sebepoškozování u jedinců $s$ kombinovaným postižením (diplomová práce) [Use of Snoezelen as a Prevention of Self-harm in Individuals with Multiple Disabilities (Diploma Thesis)]. Brno: Masarykova univerzita.

Cmajdálková, D. (2019). Strukturované vyučování v prostředí Snoezelen na základní škole speciální (diplomová práce) [Structured Teaching in a Snoezelen Environment at a Special Primary School (Diploma Thesis)]. Brno: Masarykova univerzita.

Davies, C. (2012). Creating Multi-sensory Environments: Practical Ideas for Teaching and Learning. London and New York: Routledge.

Dítětová, J. (2016). Využití konceptu Snoezelen jako prostředku k podpoře edukace na základní škole speciální (diplomová práce) [The Use of the Snoezelen Concept to Support Education at a Special Primary School (Diploma Thesis)]. Brno: Masarykova univerzita.

Filatova, R. (2014). Snoezelen-MSE. Frýdek-Místek: Kleinwächter Josef.

Filatova, R., \& Janků, K. (2011). Snoezelen. Frýdek-Místek: Kleinwächter Josef. 
Fowler, S. (2008). Multisensory Rooms and Environments: Controlled Sensory Experiences for People with Profound and Multiple Disabilities. London: Jessica Kingsley Publishers.

Grant, M. J., \& Booth, A. (2009). A Typology of Reviews: An Analysis of 14 Review Types and Associated Methodologies. Health Information and Libraries Journal, 26(2), 91-108.

Hulsegge, J., \& Verheul, A. (1997). Snoezelen - Eine andere Welt [Snoezelen - Another World]. Marburg: Lebenshilfe-Verlag.

Janků, K. (2010). Využívání metody Snoezelen u osob s mentálním postižením [Use of the Snoezelen Method in People with Intellectual Disabilities]. Ostrava: Ostravská univerzita.

Janků, K. (2018). Snoezelen v teorii, v praxi a ve výzkumu [Snoezelen in Theory, Practice and Research]. Opava: Slezská univerzita.

Krausová, V. (2013). Využití multismyslové místnosti Snoezelen a prvků bazální stimulace u dětí s těžkým postižením (diplomová práce) [Use of Multisensory Room Snoezelen and Elements of Basal Stimulation in Children with Severe Disabilities (Diploma Thesis)]. Brno: Masarykova univerzita.

Krchová, D. (2019). Snoezelen jako prostredek rozvoje smyslového vnímání u žáků se středně těžkým a těžkým mentálním postižením (diplomová práce) [Snoezelen as a Means of Developing Sensory Perception in Pupils with Moderate and Severe Intellectual Disabilities (Diploma Thesis)]. Brno: Masarykova univerzita.

Krzyžanková, L. (2006). Snoezelen jako metoda pozitivní bazální stimulace (diplomová práce) [Snoezelen as a Method of Positive Basal Stimulation (Diploma Thesis)]. Brno: Masarykova univerzita.

Macků, K. (2016). Účinnost pomůcek použivaných ve Snoezelenu u dětí s poruchou autistického spektra předškolního věku (diplomová práce) [Efficacy of Aids used in Snoezelen in Children with Autism Spectrum Disorder of Preschool Age (Diploma Thesis)]. Brno: Masarykova univerzita.

Matějíčková, S. (2019). Využití Snoezelenu pro žáky s poruchou autistického spektra (diplomová práce) [Use of Snoezelen for Pupils with Autism Spectrum Disorder (Diploma Thesis)]. Brno: Masarykova univerzita.

Matějková, L. (2018). Využití Snoezelen konceptu při edukaci žáků s těžkým mentálním postižením (diplomová práce) [The Use of the Snoezelen Concept in the Education of Pupils with Severe Intellectual Disabilities (Diploma Thesis)]. Brno: Masarykova univerzita. 
Mertens, K. (2003). Snoezelen - Eine Einführung in die Praxis [Snoezelen - An Introduction to Practice]. Dortmund: Verlag modernes Lernen.

Mertens, K. (2005). Snoezelen Anwendungsfelder in der Praxis [Snoezelen Fields of Application in Practice]. Dortmund: Verlag modernes Lernen.

Nečasová, L. (2015). Rozvoj smyslového vnímání v místnosti Snoezelen na ZŠ speciální pro žáky se středně těžkým a těžkým mentálním postižením (diplomová práce) [Development of Sensory Perception in the Snoezelen Room at a Special Primary School for Pupils with Moderate and Severe Intellectual Disabilities (Diploma Thesis)]. Brno: Masarykova univerzita.

Opatřilová, D. (2013). Edukace osob s těžkým postižením a souběžným postižením více vadami [Education of People with Severe Disabilities and Multiple Disabilities]. Brno: Masarykova univerzita.

Orieščiková, H. (2015). What will be the next special educational system? Milano: EDUCatt-Ente per il diritto allo studio universitario dell'Università Cattolica.

Orieščiková, H., \& Hrčová, J. (2010). Snoezelen. Ružomberok: Verbum.

Pagliano, P. (2001). Using a Multisensory Environment. London: David Fulton Publishers.

Pagliano, P. (2012). The Multisensory Handbook. A Guide for Children and Adults with Sensory Learning Disabilities. New York: Routledge.

Pešatová, M. (2021). Rozvoj smyslového vnímání v místnosti Snoezelen na ZŠ speciální (diplomová práce) [Development of Sensory Perception in the Snoezelen Room at Special Primary School (Diploma Thesis)]. Brno: Masarykova univerzita.

Piknerová, T. (2020). Vliv konceptu Snoezelen na sociální interakci žáků s kombinovaným postižením (diplomová práce) [The Influence of the Snoezelen Concept on the Social Interaction of Pupils with Multiple Disabilities (Diploma Thesis)]. Brno: Masarykova univerzita.

Plecháčková, M. (2009). Využití multismyslové místnosti Snoezelen u dětí se sluchovým postižením (diplomová práce) [Use of Multisensory Room Snoezelen for Children with Hearing Impairment (Diploma Thesis)]. Brno: Masarykova univerzita.

Saňáková, J. (2018). Využití konceptu bazální stimulace a metody Snoezelen na základní škole speciální (diplomová práce) [Use of the Concept of Basal Stimulation and the Method of Snoezelen at a Special Primary School (Diploma Thesis)]. Brno: Masarykova univerzita. 
Schwanecke, F. (2004). Snoezelen: Möglichkeiten und Grenzen in Verschiedenen Anwendungsbereichen [Snoezelen: Possibilities and Limits in Different Areas of Application]. Marburg: Lebenshilfe-Verlag.

Šoupalová, J. (2009). Aspekty využivání multisenzorické místnosti Snoezelen (diplomová práce) [Aspects of Using the Multisensory Room Snoezelen (Diploma Thesis)]. Brno: Masarykova univerzita.

Švarcová, I. (2011). Mentální retardace: vzdělávání, výchova, sociální péče [Mental Retardation: Education, Upbringing, Social Care]. Praha: Portál.

Vančová, A. (2010). Pedagogika viacnásobne postihnutých [Pedagogy of the Multiple Disabled]. Bratislava: Kinezis Klub Tatry.

Verheul. A. (2008). Snoezelen - Materials Homemade. Ede, Netherlands: Ad Verheul.

Vostrejšová, D. (2009). Působení Snoezelenu přistimulacijedinců s těžkým a kombinovaným postižením (diplomová práce) [The Effect of Snoezelen in the Stimulation of Individuals with Severe and Multiple Disabilities (Diploma Thesis)]. Brno: Masarykova univerzita.

Zedková, B. (2014). Možnosti využití metody Snoezelen při vzdělávání žákư s těžkým postižením a souběžným postižením více vadami (diplomová práce) [Possibilities of Using the Snoezelen Method in the Education of Pupils with Severe Disabilities and Multiple Disabilities (Diploma Thesis)]. Brno: Masarykova univerzita.

\section{Authors}

doc. PhDr. Jarmila Pipeková, Ph.D.

Faculty of Public Policies, Silesian University

Institute of Special Education

Bezručovo nám. 885/14, 74601 Opava, Czech Republic

jarmila.pipekova@fvp.slu.cz

PhDr. Jan Viktorin, Ph.D.

Faculty of Public Policies, Silesian University

Institute of Special Education

Bezručovo nám. 885/14, 74601 Opava, Czech Republic jan.viktorin@fvp.slu.cz 